\title{
МИНЕРАЛОГО-ГЕОХИМИЧЕСКИЕ ОСОБЕННОСТИ ИСТОЧНИКА ЯМКУН (ЗАБАЙКАЛЬСКИЙ КРАЙ)
}

Соктоев Булат Ринчинович', bulatsoktoev@tpu.ru

Рихванов Леонид Петрович', rikhvanov@tpu.ru

Барановская Наталья Владимировна', nata@tpu.ru

Замана Леонид Васильевич², I.v.zamana@mail.ru

Рудмин Максим Андреевич', rudminma@tpu.ru

\author{
Эпова Екатерина Сергеевна², \\ apikur1@ya.ru
}

Солодухина Мария Анатольевна², mabn@ya.ru

\author{
Этенко Константин Александрович \\ konstantin196@gmail.com
}
Михайлова Лариса Альфредасовна4, mihailova-la@mail.ru

\footnotetext{
Национальный исследовательский Томский политехнический университет, Россия, 634050, г. Томск, пр. Ленина, 30.

2 Институт природных ресурсов и криологии Сибирского отделения Российской академии наук, Россия, 672002, г. Чита, ул. Недорезова, $16 а$.

${ }^{3}$ Иркутский государственный университет, Россия, 664003, г. Иркутск, ул. Карла Маркса, 1.

4 Читинская государственная медицинская академия, Россия, 672000, г. Чита, ул. Горького, 39а.

${ }^{5}$ Краевой центр медицинской реабилитации «ямкун», Россия, Забайкальский край, Газимуро-Заводский район, с. Ямкун, ул. Рабочая, 1.
}

Актуальность. Источник Ямкун известен как один из немногих радиоактивных источников на территории Забайкальского края. Его воды ранее использовались для лечения болезни Кашина-Бека (уровской болезни), в настоящее время на его базе функционирует краевой центр медицинской реабилитации для лечения заболеваний костно-мышечной, нервной систем, в том числе ДЦП, а также заболеваний кожи.

Цель: выявление минералого-геохимических особенностей компонентов источника Ямкун.

объекты: воды озера, ручья, травертины, железистые осадки в русле ручья, солевые отложения на трубе каптажного колодца, растительность (лишайники, мхи, хвоя сосны, листья тополя).

Методы: масс-спектрометрия с индуктивно связанной плазмой, инструментальный нейтронно-активационный анализ, рентгеновская дифрактометрия, сканирующая электронная микроскопия.

Результаты. Воды источника Ямкун являются гидрокарбонатными кальциево-магниевыми, радиоактивными радоновой природы. Они существенно обогащены Mn, Fe, Be, As, Zr, Cs, Hg, Tl, Li, Co, Ba относительно воды оз. Байкал. Обогащение воды редкими щелочными и щелочноземельными элементами (Li, Be, Cs), а также $\mathrm{Hg}$, Tl, As и Zr позволяет предположить, что их источником являются редкометалльные гранитоиды. При разгрузке вод наблюдается современное минералообразование в виде "ямкунской пены» (арагонит) на поверхности водных ванн, трубах каптажного колодца (несквегонит) и ручье (железистые осадки). Железистые осадки и травертины представлены в основном магнезиальным кальцитом. При этом в железистых осадках выявлены в больших количествах соединения Fе и Mn, вероятно гидроксиды. В гидроксидах $\mathrm{Mn}$ встречаются также соединения Ba, K, Cl, в гидроксидах Fe - As, P, Si, Al. Из редких микровключений в травертинах отмечены интерметаллические соединения Си и Sn, La-Cе карбонат, а также сульфид As (леллингит?). Установлена унаследованность состава современных железистых осадков и травертинов. Образующиеся травертины обогащены теми же элементами, что и вода в источнике.

\section{Ключевые слова:}

Ямкун, минеральные воды, травертины, железистые осадки, минеральный состав, химический состав

\section{Введение}

Минеральные источники различного типа привлекают внимание ученых всего мира [1, 2]. Ключевыми вопросами, рассматриваемыми в публикациях, являются: 1) взаимодействие в системе «вода-порода» [3-6]; 2) геохимия широкого спектра химических элементов в создаваемых экстремальных условиях [7, 8]; 3) минералогия и геохимия формирующихся отложений [9-17].

Район Забайкалья издавна известен своими минеральными источниками различного типа. В начале XX в. профессор И.А. Багашев в своей моно- 


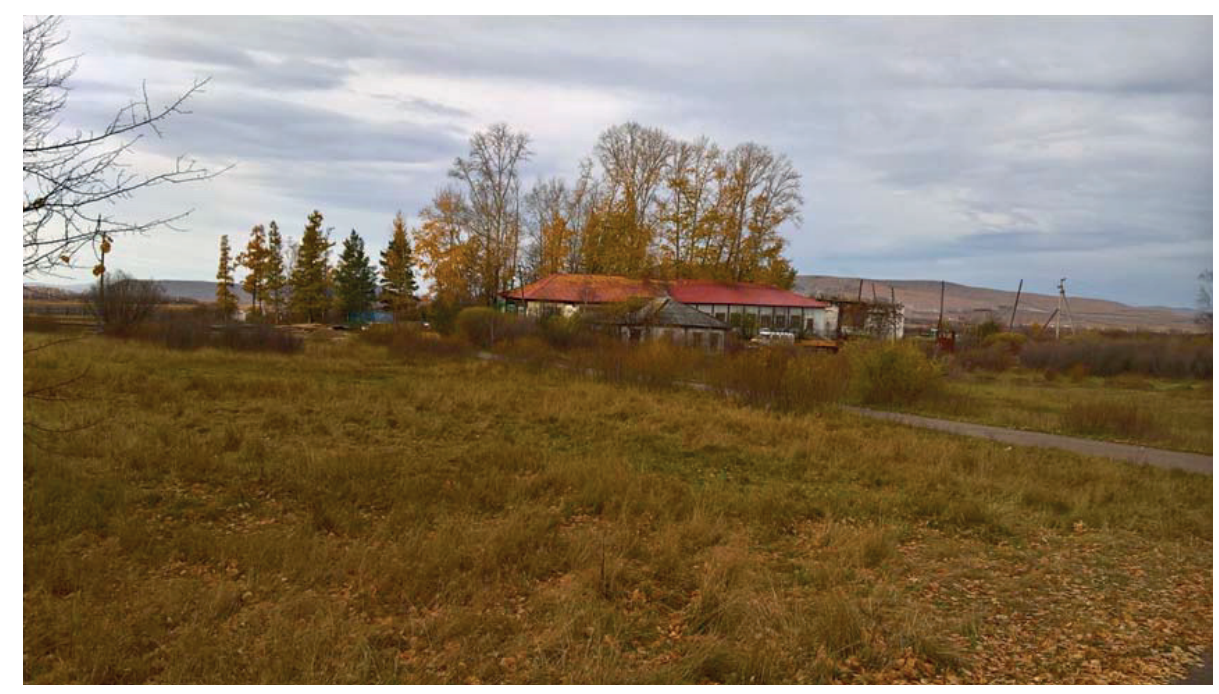

Pис. 1. Здание ванного корпуса. Слева от здания среди деревьев находится основной источник в виде небольшого озера

Fig. 1. Bathroom building. The main spring presented by a small lake is located among the trees to the left of the building

графии описывает и показывает на карте 163 минеральных источника, различных по температуре, дебиту и использованию местным населением [18]. Согласно ранее опубликованным работам, данным вопросом на территории региона начали заниматься уже в XVIII в. (И.Г. Гмелин, И.Г. Георги, П.С. Паллас и другие).

В Забайкальском крае наибольшее распространение имеют холодные углекислые источники (80\% от общего количества). Меньше распространены холодные пресные радоновые, железистые и сероводородные воды. К отдельным гидротермальным районам приурочены термальные азотные и азотно-углекислые (север, юго-запад, юго-восток региона), холодные высокоминерализованные и рассольные (Каларский район), холодные сероводородные (Красночикойский район) воды [19-22].

Среди наиболее известных у населения источников Дарасун, Кука, Молоковка, Ямаровка особняком стоит источник Ямкун, уже в начале XX в. отнесенный И.А. Багашевым к числу самых радиоактивных на тот временной период, исключая Молоковку [23].

История минеральных вод Ямкуна (от бурятского «Ял-Гунь» - бездна) берет свое начало с середины XVIII в. [18]. В настоящее время на базе Ямкуна функционирует краевой центр медицинской реабилитации (рис. 1).

В литературе Ямкун описан в трёх вариациях, изложенных в [18]. По первому описанию М.А. Злобина в 1823 г. он представлял источник, залегающий в ноздреватых пепельно-серых известковых породах, под которыми «... лежит илова тал тундристая зелля с галькали известняка. Вероятно, что сей водоел есть остаток бывшего в прежние врелена горячего ключа ...». Позднее Г.Б. Пранг (1844) характеризует Ямкун следующим образом: «... представляет три водовлестилища. 1. илеет вид эллипса с длинной осью до трёх сажень; 2. в двух аршинах от первого, десять вершков в диалетре и 3. в двух саженях от второго - 1 сажень в диалетре ...». Он также отмечает, что вмещающими породами является известковый туф. Последующее описание в 1868 г., сделанное A.М. Ломоносовым, дает нам представление о том, что длина озера составляет 8 саженей, ширина 6 саженей. «... Это глубокая яла, трёх саженей глубиною... Вокруг озера значительное количество небольших ялок, из которых бьют ключи, обилующие углекислыл газол». Перечисленные данные указывают на непостоянное состояние источника, обусловленное в том числе и деятельностью человека.

K XIX в. также относится упоминание так называемой «ямкунской пены», которая представляла собой порошок, собранный с поверхности воды при кипячении и впоследствии высушенный. Он оказывал большой терапевтический эффект при лечении кожных болезней [18].

Целебные свойства воды и порошка позволяют отличить углекисло-железистые воды Ямкуна от других минеральных вод такого типа. Сама вода стала использоваться местными купцами для лечения с 1830 г., а позднее, в 1868 г., источник перешел в Управление Нерчинского горного округа. Со временем Ямкун стал одним из самых посещаемых мест лечения Забайкалья и не только. Особенную популярность он приобрел при лечении болезни Кашина-Бека (уровской болезни): в 1929 г. на его базе была создана Уровская научно-исследовательская станция по изучению этого эндемического заболевания, которая просуществовала до 1993 г. Сегодня на базе источника функционирует краевой центр медицинской реабилитации, специализирующийся на лечении людей с заболеваниями костно-мышечной, нервной систем, в том числе с ДЦП, а также заболеваниями кожи. Эффективность лечения высокая, особенно детей с 
ДЦП. В год обслуживается около 1500 человек, из них детей с ДЦП - порядка 200 человек. К сожалению, сегодняшнее экономическое положение данного уникального природного объекта бедственное. А этот уникальный по своим свойствам источник весьма бы пригодился для оздоровления рабочих с новых горнорудных предприятий региона (Быстринский, Ново-Широкинский ГОКи и другие), а также населения при профилактике уровской болезни и для лечения детского церебрального паралича.

\section{Общая характеристика местности}

Согласно предыдущим исследованиям, минералого-геохимические особенности источника охарактеризованы в основном с точки зрения химического состава воды. На данный момент опубликовано много гидрогеохимических данных, но они носят разрозненный характер и, соответственно, отсутствует системное описание. Наиболее подробная информация по Ямкуну представлена в работах И.А. Багашева (1905) и в рукописной работе В.А. Кротовой «Минеральные источники Восточного Забайкалья» (1944). Из последних публикаций стоит отметить работы сотрудников Института земной коры СО РАН (г. Иркутск) [24] и Института природных ресурсов, экологии и криологии СО РАН (г. Чита) [25, 26].

Проведенный в середине XIX в. химический анализ воды озера показывает наличие многих элементов и соединений. Так, А.М. Ломоносов определил в 300 литрах воды содержание $\mathrm{Li}, \mathrm{Sr}, \mathrm{Ba}$, $\mathrm{Cu}, \mathrm{Pb}, \mathrm{Al}_{2} \mathrm{O}_{3}, \mathrm{~N}_{2} \mathrm{O}_{5}, \mathrm{Br}, \mathrm{Fl}$ (вероятно фтор). И.А. Багашев в своей книге указывает, что в 1894 г. был проведен химический анализ высушенного при $125{ }^{\circ} \mathrm{C}$ порошка, который показал наличие в нем хлора, серного ангидрита, сероводорода, фосфор- ного ангидрита, углекислоты, закиси железа, закиси марганца, окиси кальция, окиси магния, окиси калия, окиси натрия, аммиака, органического вещества [18].

Источник Ямкун приурочен к впадине, сложенной известняками и доломитами быстринской свиты нижнего кембрия, которые сверху перекрыты маломошными четвертичными отложениями. По зоне трещиноватости Газимуровский Завод - Ямкун - Корабль - Золь - Уровские Ключи [27] разгружаются воды в виде нескольких источников, образующих цепочку, вытянутую в юго-восточном направлении. Основной источник представляет собой водоём размером $10 \times 20 \mathrm{~m}$, с площадью водной поверхности около $160 \mathrm{~m}^{2}$ (рис. 2), из которого вытекает слабопроточный ручей, который теряется у забора, ограждающего территорию санатория. Однако развитие травертинов за забором и дорогой позволяет предположить, что ранее ручей имел бо́льшую протяженность, около 250-300 м. В целом современное состояние источника походит на описание, сделанное Г.Б. Прангом [18], разнятся только оценки размеров выходов.

Озеро приурочено к травертинам («туфам» в терминологии И.А. Багашева и других авторов), которые обнажаются на северо-восточном берегу водоема. Выходы травертинов были выявлены также и в других местах. Ряд авторов этот выход травертинов называет куполом в виде пологого конуса, на вершине которого расположено озеро [28].

Вода в озере имеет температуру $20-25{ }^{\circ} \mathrm{C}$ и не опускается ниже $10{ }^{\circ} \mathrm{C}$ даже в самые сильные морозы [18]. В ручье, который вытекает из источника, температура несколько выше и достигает 30-32 ${ }^{\circ} \mathrm{C}$, вода в источнике субтермальная.

Периодически в разных местах водоёма вода «вскипает» из-за выделения газов (рис. 3).

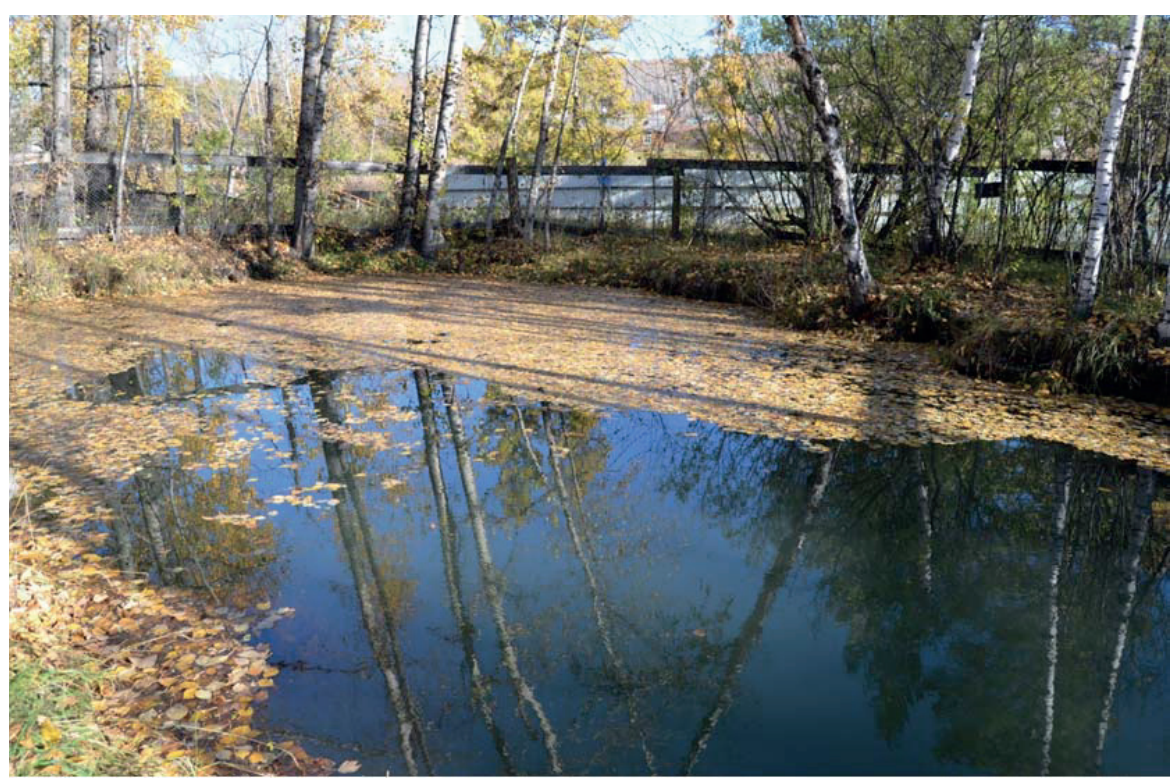

Pис. 2. Основной водоем Я.мкуна

Fig. 2. Main water reservoir of Yamkun 


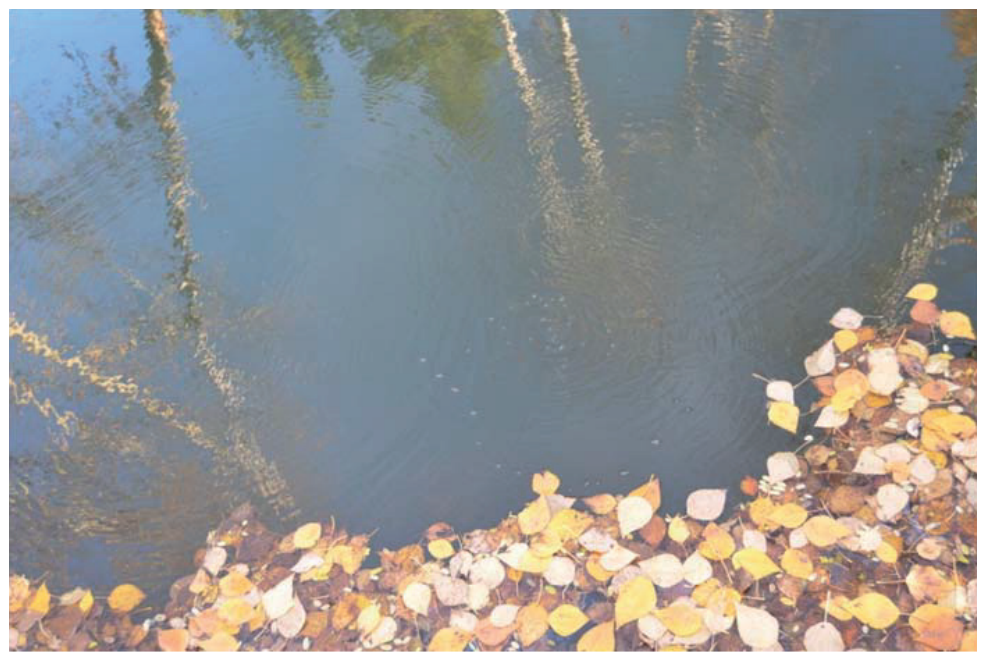

Рис. 3. Выделение газа со дна озера

Fig. 3. Gas release from the lake bottom

Выполненный в 1928 г. газовый анализ проб, о которых сообщает В.А. Кротова (1944), и исследования 2015 г. [24], показывают, что в составе вод источника преобладают $\mathrm{N}_{2}(53,2 \%-1928$ г.; $77,9 \%-2015$ г.) и $\mathrm{CO}_{2}(46$ и $21 \%$, соответственно). В небольших количествах также обнаружены $\mathrm{He}, \mathrm{H}_{2}, \mathrm{O}_{2}, \mathrm{CH}_{4}[24]$.

Воды источника Ямкун являются радиоактивными (рис. 4), природа радиоактивности радоновая. Согласно различным данным, радиоактивность колебалась от 217 до 550 ед. Махе при среднем значении 290 [23] и 286 ед. Махе (П.П. Орлов, устное сообщение), что в системе СИ составляет $2700-2800$ Бк/л - такие показатели соответствуют параметрам радиоактивной воды.
Мощность экспозиционной дозы (МЭД), согласно данным сигнализатора-индикатора $\gamma$-излучения СИГ-РМ1208 (Белоруссия), колеблется от 0,20 до 0,79 мкЗ/ч. Максимальные значения отмечены в местах интенсивного выпадения железистых осадков в ручье (рис. 5).

Следует отметить, что вода в источнике и каптажном колодце отличается по активности радона: 44 и 110 эман (150 и 468 Бк/л), соответственно. В то же время эти значения намного выше, чем активность вод из скважин, пройденных Сибирской гидрогеологической партией объединения «Лечминресурсы», где она составляла от 1,5 до 9,7 эман [28]. Судя по этим результатам, в данной системе есть несколько источников, обуславливающих по-

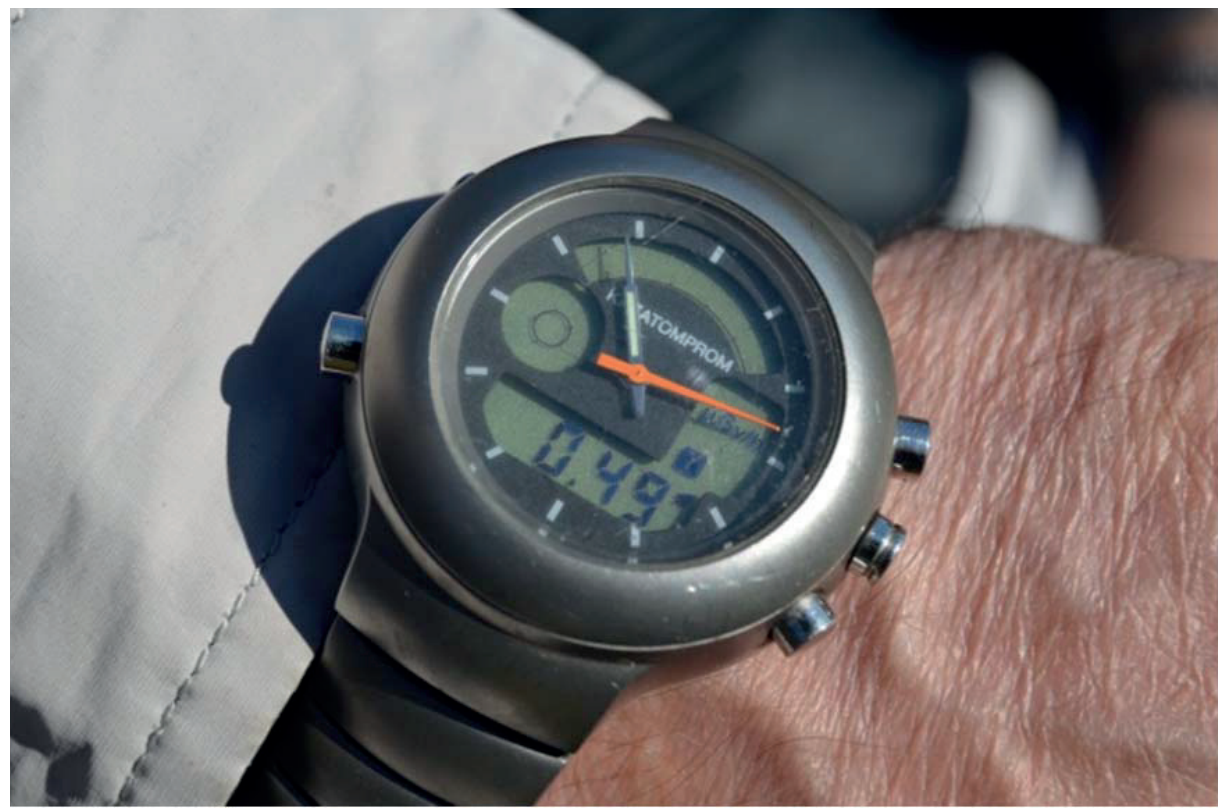

Pис. 4. Мощность экспозиционой дозы над ручьём в воздухе на высоте 1 м, мк3/ч

Fig. 4. Exposure dose rate in the air above the spring at the height of $1 \mathrm{~m}, \mathrm{mcSv} / \mathrm{h}$ 


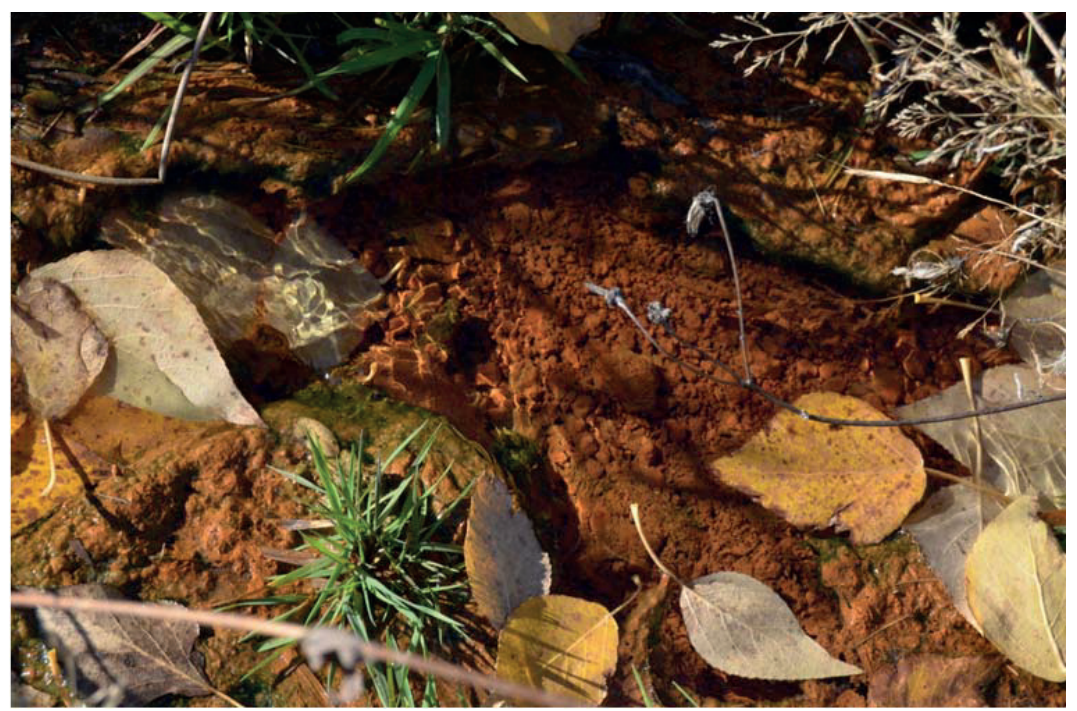

Рис. 5. Железистые осадки в ручье

Fig. 5. Ferruginous sediments in the spring

вышенную радиоактивность. Одним из них может являться купол травертинов [27], о чем косвенно свидетельствуют повышенные содержания $\mathrm{Ra}$ $\left(43 \cdot 10^{-10}\right.$ вес. \%) в этих породах [28].

\section{Материалы и методы исследования}

В сентябре 2017 г. нами были отобраны пробы природных вод из двух источников (озеро, ручей), выходов травертинов вокруг озера и вдоль ручья, железистых осадков из ручья, солевых отложений, образовавшихся на трубе в каптажном колодце (рис. 6). Дополнительно исследовался солевой осадок в виде порошка, собранный ранее (2014 г.) с поверхности воды в баке, который используется для подогрева воды. Мы полагаем, что это та самая знаменитая «ямкунская пена», о которой упоми-

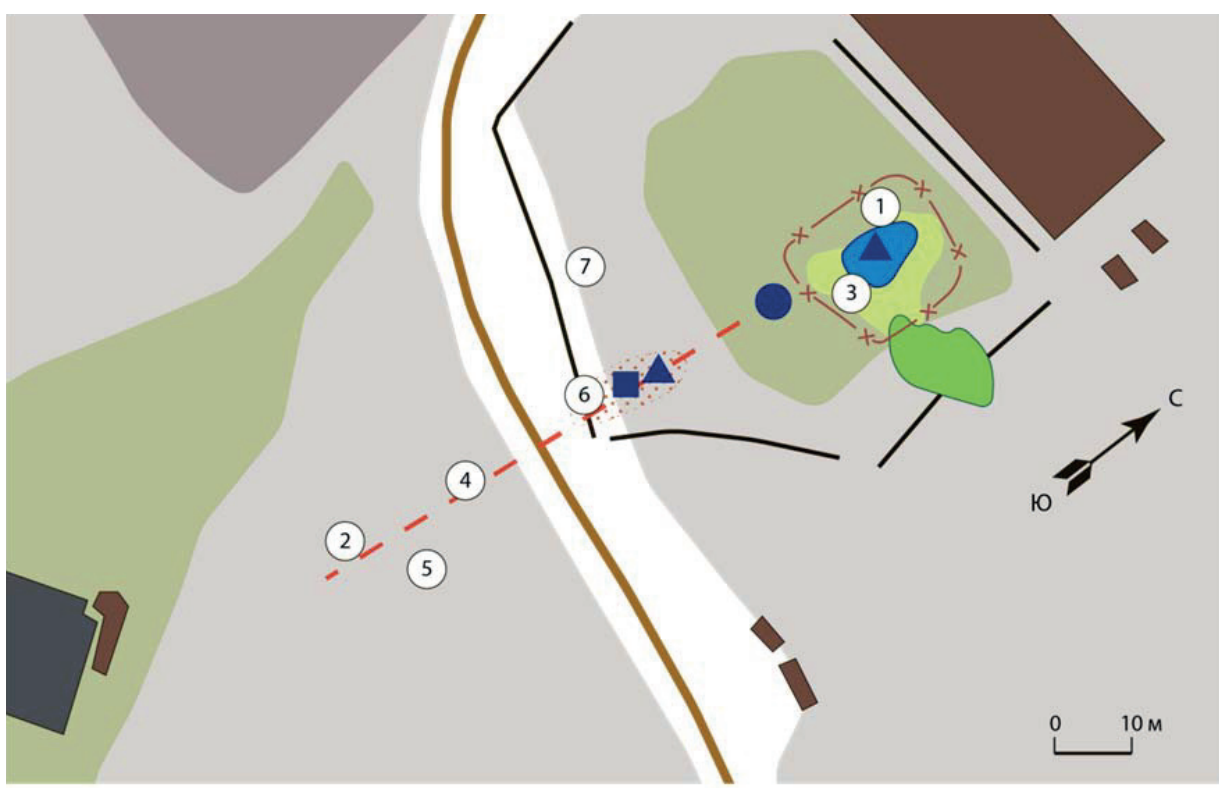

(1) - проба травертинов и ее номер

- проба воды

- проба железистых осадков

- каптажное устройство, на трубе

которого отобраны солевые отложения $\because-$-железистые осадки в тальвеге ручья

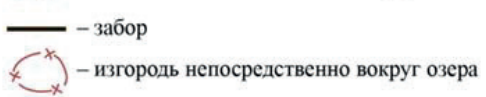

Puc.6. Схема отбора проб

Fig. 6. Sampling scheme 
налось выше. Кроме того, в непосредственной близости к озеру и ручью были отобраны биогеохимические пробы, представленные листьями тополя, хвоей сосны, мхом, лишайниками.

Отобранные пробы были проанализированы современными аналитическими методами в лабораториях Национального исследовательского Tомского политехнического университета (НИ ТПУ).

Анализ природных вод. Анализ проб воды выполнен в проблемной научно-исследовательской лаборатории гидрогеохимии научно-образовательного центра «Вода» НИ ТПУ (аттестат аккредитации № POCC RU.0001.511901 от 26.09.2018 г.). Элементный состав проб определен методом массспектрометрии с индуктивно-связанной плазмой (ICP-MS) на масс-спектрометре NexION 300D coгласно методике HCAM 480X (аналитик Ю.Н. Буткевич). Пробы для анализа предварительно не фильтровались. Всего было проанализировано содержание 71 компонента (без учета гидрогеохимических показателей), при этом содержание P, Sc, V, Ga, Ge, Se, Br, Ag, Cd, Sn, Pr, Sm, $\mathrm{Eu}, \mathrm{Gd}, \mathrm{Tb}, \mathrm{Dy}, \mathrm{Ho}, \mathrm{Er}, \mathrm{Tm}, \mathrm{Yb}, \mathrm{Lu}, \mathrm{Re}, \mathrm{Pb}$, Th оказалось ниже предела определения.

Анализ твердой фазы и биогеохимических проб. Элементный состав отобранных проб был изучен с использованием метода инструментального нейтронно-активационного анализа (ИНАА) в ядерно-геохимической лаборатории Международного инновационного научно-образовательного центра (МИНОЦ) «Урановая геология» на базе исследовательского ядерного реактора ИРТ-Т НИ ТПУ (аттестат аккредитации № RA.RU.21AБ27 от 27.05.2015 г., аналитики - А.Ф. Судыко, Л.В. Богутская). Плотность потока тепловых нейтронов в канале облучения составляла $2 \cdot 10^{13}$ нейтр. $/\left(\mathrm{cm}^{2} \cdot \mathrm{c}\right)$. Продолжительность облучения проб 20 часов. Измерение производилось на многоканальном анализаторе импульсов АМА 02Ф с полупроводниковым $\mathrm{Ge}-\mathrm{Li}$ детектором ДГДК-63А. Было определено содержание 28 химических элементов ( $\mathrm{Na}, \mathrm{Ca}, \mathrm{Sc}$, $\mathrm{Cr}, \mathrm{Fe}, \mathrm{Co}, \mathrm{Zn}, \mathrm{As}, \mathrm{Br}, \mathrm{Rb}, \mathrm{Sr}, \mathrm{Ag}, \mathrm{Sb}, \mathrm{Cs}, \mathrm{Ba}, \mathrm{La}, \mathrm{Ce}$, $\mathrm{Nd}, \mathrm{Sm}, \mathrm{Eu}, \mathrm{Tb}, \mathrm{Yb}, \mathrm{Lu}, \mathrm{Hf}, \mathrm{Ta}, \mathrm{Au}, \mathrm{Th}, \mathrm{U})$. Метрологические параметры и правильность анализа имеют удовлетворительные параметры.

Вещественный состав образцов травертинов, железистых осадков и солевых отложений был определен методами порошковой рентгеновской дифрактометрии (дифрактометр D2 Phaser, учебно-научная лаборатория оптической и электронной микроскопии МИНОЦ «Урановая геология» НИ ТПУ) и сканирующей электронной микроскопии (микроскоп TESCAN VEGA 3 SBU, отделение геологии Инженерной школы природных ресурсов НИ ТПУ). Параметры съемки на рентгеновском дифрактометре: анод - $\mathrm{Cu}$ (медь), напряжение рентгеновской трубки - 30 кВ, ток - 10 мА. Углы съемки $2 \theta$ при валовом анализе состава пробы составляли от $8^{\circ}$ до $70^{\circ}$, вращение - 10 об./мин, выдержка $-1,5$ сек в точке, шаг $-0,02^{\circ}$. Параметры съемки на сканирующем электронном микроско- пе: ускоряющее напряжение - 20 кВ, ток 4-12,2 нА. Рентгеноспектральный анализ и определение минеральных микровключений производились на шлифах, покрытых тонким слоем углерода (30 нм), с использованием приставки для рентгенофлуоресцентного энергодисперсионного анализа OXFORD X-Max 50 с $\mathrm{Si} / \mathrm{Li}$ кристаллическим детектором.

\section{Результаты и их обсуждение}

Общие гидрогеохимические характеристики вод мало отличаются от известных ранее данных. Воды как в озере, так и в ручье являются гидрокарбонатными кальциево-магниевыми (наименование химического состава воды согласно отраслевому стандарту ОСТ 41-05-263-86), минерализация составляет около 2 г/дм ${ }^{3}$ (табл. 1).

таблица 1. Хилический состав изученных вод

Table 1. Chemical composition of the studied waters

\begin{tabular}{|c|c|}
\hline $\begin{array}{l}\text { Место отбора } \\
\text { Sampling site }\end{array}$ & $\begin{array}{l}\text { Формула химического состава } \\
\text { Chemical composition formula }\end{array}$ \\
\hline $\begin{array}{l}\text { Oзеро } \\
\text { Lake }\end{array}$ & 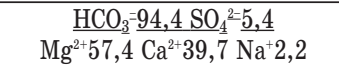 \\
\hline $\begin{array}{l}\text { Ручей } \\
\text { Stream }\end{array}$ & $\underset{\mathrm{Mg}^{2+} 58,5}{\underline{\mathrm{HCO}_{3}}}=\frac{=95,0 \mathrm{SO}_{4}{ }^{2-}}{\mathrm{Ca}^{2+} 38,5,5} \frac{4,9}{\mathrm{Na}^{+} 2,3}$ \\
\hline
\end{tabular}

Содержания $\mathrm{Fe} \quad\left(1,4-2,9\right.$ мг/дм $\left.{ }^{3}\right) \quad$ и $\quad \mathrm{Si}$ (11,6-11,8 мг/дм³), по данным ICP-MS, не достигают принятых бальнеологических норм для отнесения к лечебным по этим показателям (10 и 18 мг/дм ${ }^{3}$ соответственно), поэтому воду нельзя отнести ни к одному из выделенных в ГОСТ Р 54316-2011 бальнеологическому типу углекислых вод Забайкалья (дарасунский, кукинский). Ее основным лечебным фактором служит углекислова и радон. Но для пациентов, страдающих от уровской болезни, очевидно особое значение имеет высокое содержание кальция в воде.

Выполненное нормирование относительно воды из оз. Байкал [29] показывает, что для ряда компонентов (Mn, Fe, Be, As, $\mathrm{Zr}, \mathrm{Cs}, \mathrm{Hg}, \mathrm{Tl})$ характерны коэффициенты концентрации (КК) более 100. Близкие к $100 \mathrm{KК}$ наблюдаются также для $\mathrm{Li}$, $\mathrm{Mg}$, Со (рис. 7). Этот геохимический спектр уникален по своим ассоциациям: с одной стороны, мы наблюдаем $\mathrm{Fe}, \mathrm{Mn}, \mathrm{Mg}$, с другой стороны - редкие щелочные и щелочноземельные элементы $(\mathrm{Li}, \mathrm{Be}$, $\mathrm{Cs).} \mathrm{Также} \mathrm{примечательной} \mathrm{является} \mathrm{третья} \mathrm{груп-}$ па элементов ( $\mathrm{Hg}, \mathrm{Tl}, \mathrm{As})$. Особняком выглядит $\mathrm{Zr}$, но с точки зрения возможных источников поступления химических элементов в воду, он помогает понять их происхождение. С большой долей вероятности таковыми являются редкометалльные гранитоиды. Об этом же могут свидетельствовать высокие КК ряда редкоземельных элементов.

Из вод озера в дальнейшем на трубе в каптажном колодце выпадают солевые отложения, а также образуется в виде налета так называемая «пена». Кроме того, в ручье наблюдается выпадение железистых осадков. 
Рентгенофазовый анализ показывает, что травертины в основном сложены магнезиальным кальцитом с примесями арагонита и кварца, за исключением пробы № 2, в составе которой выявлены также альбит, микроклин и мусковит (табл. 2). «Пена» на 100 \% состоит из арагонита, а солевые отложения на трубе в каптажном колодце представлены достаточно редким минералом - несквегонитом, водным карбонатом магния $\left(\mathrm{MgCO}_{3} \cdot 3 \mathrm{H}_{2} \mathrm{O}\right)$.

Таблица 2. Минеральный состав проб

Table 2. Mineral composition of the samples

\begin{tabular}{|c|c|c|c|c|c|c|c|}
\hline \multirow[b]{2}{*}{$\begin{array}{c}\text { Пробы } \\
\text { Samples }\end{array}$} & \multicolumn{7}{|c|}{ Минералы/Minerals, \% } \\
\hline & 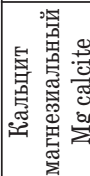 & 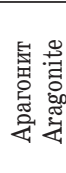 & 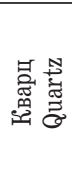 & 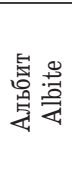 & 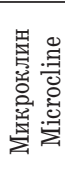 & 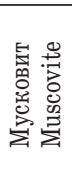 & 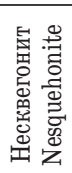 \\
\hline 1 & 88,2 & 10,2 & 1,6 & - & - & - & - \\
\hline 2 & 24,0 & - & 19,9 & 20,4 & 23,1 & 12,6 & - \\
\hline 3 & 81,4 & 18,6 & - & - & - & - & - \\
\hline 4 & 84,8 & 15,2 & - & - & - & - & - \\
\hline 5 & 94,9 & 4,3 & 0,8 & - & - & - & - \\
\hline 6 & 89,3 & 8,9 & 1,8 & - & - & - & - \\
\hline 7 & 98,5 & - & 1,5 & - & - & - & - \\
\hline 8 & - & 100 & - & - & - & - & - \\
\hline 9 & - & - & - & - & - & - & 100 \\
\hline 10 & 97,9 & - & 2,1 & - & - & - & - \\
\hline
\end{tabular}

Прилечание: 1-7 - травертины; 8 - «пена»; 9 - солевые отложе ния на трубе; 10 - железистые осадки в ручье.

Note: $1-7$ - travertines; 8 - «foam»; 9 - salt deposits on the tube; 10 ferruginous deposits in the spring.

Полученные данные ИНАА свидетельствует о выдержанном элементном составе образцов травертинов, «пены», солевых отложений и желези- стых осадков (табл. 3). Среди проб травертинов необходимо обратить внимание на пробу 2 , где содержания $\mathrm{Zn}, \mathrm{Rb}$, Th, редкоземельных элементов максимальны для данной выборки. Для «пены» характерно максимальные содержания $\mathrm{Sr}$ (1431 г/т) и U (13,6 г/т), а также повышенные концентрации As, Ce. Для солевых отложений с трубы каптажного колодца не выявлено значимых концентраций изученных химических элементов, за исключением $\mathrm{Au}$, содержание которого на порядок выше, чем в других образцах. Весьма интересно с геохимической точки зрения смотрятся железистые осадки, выпадающие в ручье. Для данных отложений характерно максимальное содержание $\mathrm{Fe}-9,9 \%$, а также Co $(175,9$ г/т), As $(2305,6$ г/т), $\operatorname{Br}(6,3$ г/т), Sb (156,5 г/т). Практически такой же спектр химических элементов (Co, $\mathrm{As}, \mathrm{Sb}, \mathrm{Ba})$ в повышенных концентрациях выявлен в образце травертина, отобранном в непосредственной близости (проба № 6).

В целом выходы травертинов на источнике Ямкун формируют значительное по площади поле и характеризуются различными текстурно-структурными особенностями (рис. 8). Текстура породы ячеисто-скорлуповатая, кавернозная, пористая. Окраска изменяется от темно-серой до светло-серой, иногда белесой. В отдельных случаях наблюдаются полосчатые горизонты, обусловленные чередованием светлых и темных разностей пород. В проходящем свете видно, что темная окраска определяется большим количеством органического вещества, гидроокислов $\mathrm{Fe}$ и $\mathrm{Mn}$. В ряде случаев на удалении от источника наблюдается метасоматическое замещение осадочных пород (гравелитов) карбонатным материалом. При этом отчетливо наблю-

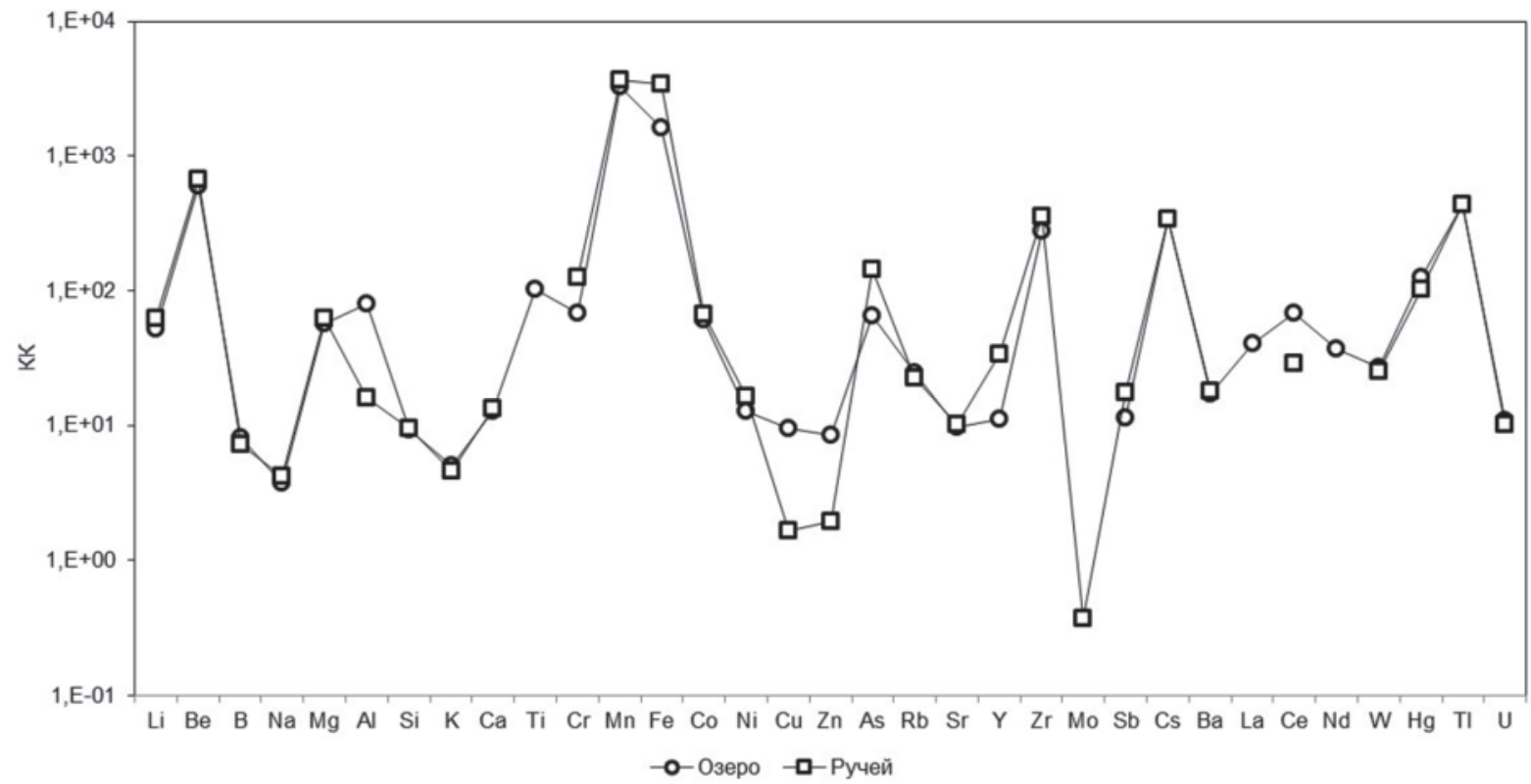

Pис. 7. Норлированные на средний состав байкальской воды спектры содержания хилических элелентов в изученных водах. Прилечание: $К К$ - коэффициент концентрации относительно среднего состава байкальской воды [29]

Fig. 7. Spectra of chemical elements in studied waters normalized by the average composition of Lake Baikal water. Note: KK is the concentration coefficient relative to the average composition of Lake Baikal water [29] 
Таблица 3. Элементный состав травертинов и различных отложений из вод по данным ИНАA, г/m

Table 3. Element composition of the travertines and various deposits, precipitated out of the water, according to INAA, ppm

\begin{tabular}{|c|c|c|c|c|c|c|c|c|c|c|}
\hline \multirow{2}{*}{$\begin{array}{l}\text { Элемент } \\
\text { Element }\end{array}$} & \multicolumn{10}{|c|}{ Пробы/Samples } \\
\hline & 1 & 2 & 3 & 4 & 5 & 6 & 7 & 8 & 9 & 10 \\
\hline $\mathrm{Na}$ & 220 & 160 & 140 & 200 & 520 & 8180 & 330 & 220 & 190 & 950 \\
\hline $\mathrm{Ca}$ & 239700 & 259800 & 269400 & 295800 & 243300 & 155900 & 259500 & 285500 & 4090 & 170800 \\
\hline $\mathrm{Cr}$ & 9,97 & 10,03 & 10,81 & 11,82 & 69,44 & 58,93 & 24,35 & 4,33 & 0,87 & 3,78 \\
\hline $\mathrm{Fe}$ & 4640 & 8500 & 8890 & 1130 & 34310 & 13250 & 23190 & 5110 & 780 & 98520 \\
\hline Co & 17,5 & 38,1 & 10,7 & 0,765 & 67,4 & 13,9 & 51,6 & 1,023 & 0,379 & 175,9 \\
\hline As & 74,3 & 195,9 & 209,4 & 8,3 & 950,0 & 133,0 & 616,0 & 82,7 & 21,4 & 2305,6 \\
\hline $\mathrm{Br}$ & 1,312 & 1,226 & 1,230 & 0,422 & 2,945 & 1,099 & 2,113 & 0,221 & 0,779 & 6,262 \\
\hline $\mathrm{Rb}$ & 1,05 & $<2$ & $<2$ & 1,48 & $<2$ & 70,0 & $<2$ & $<2$ & 2,00 & $<2$ \\
\hline $\mathrm{Sr}$ & 430,4 & 247,9 & 470,9 & 387,6 & 400,8 & 400,0 & 292,6 & 1431,3 & 21,4 & 351,8 \\
\hline $\mathrm{Ag}$ & $<0,7$ & $<0,7$ & 46,7 & $<0,7$ & $<0,7$ & $<0,7$ & $<0,7$ & $<0,7$ & 5,1 & $<0,7$ \\
\hline $\mathrm{Sb}$ & 5,81 & 11,67 & 7,19 & 0,58 & 44,85 & 15,28 & 24,68 & 2,91 & 3,08 & 156,5 \\
\hline $\mathrm{Ce}$ & 2,96 & 1,67 & 1,56 & 1,93 & 4,44 & 21,5 & 3,70 & 5,14 & 1,87 & 5,11 \\
\hline $\mathrm{Nd}$ & 3,57 & 6,49 & 4,30 & 2,68 & 4,01 & 8,52 & $<1$ & 7,02 & 1,32 & $<1$ \\
\hline $\mathrm{Sm}$ & 0,131 & 0,075 & 0,064 & 0,082 & 0,205 & 1,319 & 0,265 & 0,124 & 0,034 & 0,548 \\
\hline $\mathrm{Eu}$ & 0,015 & 0,038 & 0,004 & 0,008 & 0,031 & 0,286 & $<0,02$ & 0,021 & 0,001 & 0,024 \\
\hline $\mathrm{Tb}$ & 0,006 & 0,006 & $<0,1$ & 0,008 & $<0,1$ & 0,183 & $<0,1$ & $<0,1$ & $<0,1$ & $<0,1$ \\
\hline $\mathrm{Yb}$ & 0,097 & 0,064 & 0,080 & 0,036 & 0,168 & 0,620 & 0,213 & 0,086 & 0,023 & $<0,8$ \\
\hline $\mathrm{Lu}$ & 0,030 & 0,022 & 0,025 & 0,026 & 0,045 & 0,074 & 0,033 & 0,098 & 0,031 & 0,092 \\
\hline $\mathrm{Hf}$ & $<0,5$ & 0,103 & $<0,5$ & 0,051 & $<0,5$ & 1,275 & $<0,5$ & 0,132 & 0,045 & $<0,5$ \\
\hline $\mathrm{Ta}$ & $<0,08$ & 0,007 & $<0,08$ & $<0,08$ & $<0,08$ & 0,359 & $<0,08$ & $<0,08$ & $<0,08$ & $<0,08$ \\
\hline $\mathrm{Au}$ & 0,006 & 0,0001 & $<0,003$ & $<0,003$ & 0,002 & 0,004 & $<0,003$ & 0,005 & 0,011 & $<0,003$ \\
\hline Th & 0,225 & 0,088 & 0,068 & 0,123 & 0,249 & 2,450 & 0,144 & 0,214 & 0,199 & 0,234 \\
\hline
\end{tabular}

Примечание: «<»- ниже предела обнаружения; 1-7 - травертины; 8- «пена»; 9 - солевые отложения на трубе; 10 - железистые осадки в ручье.

Note: «<»-below detection limit; 1-7-travertines; 8 - «foam»; 9 - salt deposits on the tube; 10 - ferruginous deposits in the spring.

даются реликты незамещенных галек, представленных кварцем, полевыми шпатами (рис. 8, $d$ ).

Минеральный состав травертинов выдержан (табл. 2): во всех пробах преобладает магнезиальный кальцит (81-94 \%), присутствует арагонит $(4-15 \%)$ и в ряде образцов кварц $(0,8-1,6 \%)$. По нашему мнению, кварц является реликтовым, так же как в образце № 2, в котором обнаружены окатанные обломки кварца и полевых шпатов (табл. 2).

В геохимическом аспекте все разнообразие травертинов достаточно выдержано. В образцах, более обогащенных гидроксидами $\mathrm{Fe}$ и $\mathrm{Mn}$ (проба № 6), фиксируются высокие значения $\mathrm{Cr}, \mathrm{Co}, \mathrm{As}, \mathrm{Sb}, \mathrm{Ba}$. В образце с сохранившимися реликтами исходных пород (гравелиты) отмечается повышенное содержание $\mathrm{Na}, \mathrm{Zn}, \mathrm{Cr}$, редкоземельных элементов и пониженное содержание Са (табл. 3).

Электронно-микроскопические исследования образцов травертинов, железистых осадков, «пены» и солевых отложений на трубе каптажного колодца позволили выявить ряд минералов-концентраторов химических элементов. Наиболее «богатыми» в минеральном составе оказались железистые осадки, образующиеся в ручье.

Основная масса железистых осадков на 80-90 \% сложена карбонатом Са (до 38,6 мас. \%) с примесями $\mathrm{Mg}$ (до 1,8 мас. \%), что подтверждает данные рентгеновской дифрактометрии. Иногда в этих осадках наблюдается некоторая зональность (рис. 9, a).

В пространстве между агрегатами карбоната, а иногда в виде концентрически-зональных корковых, коллоидных образований встречаются соединения $\mathrm{Mn}$ (вероятно, гидроксиды) с различным набором примесных элементов. Так, в сфероиде (рис. 9, b) содержание $\mathrm{Mn}$ по данным рентгеноспектрального анализа составляет $38,8-40,5$ мас. \% . В виде примеси в нем фиксируются $\mathrm{Fe}(0,4-5,6$ мас. \%), $\mathrm{Ba}$ $(1,1-1,4$ мac. $\%), \mathrm{K}(0,3-0,7$ мac. $\%), \mathrm{Cl}(0,1-0,4$ мac. $\%)$, $\mathrm{Na}(0,3$ мac. $\%)$.

Соединения Fe (вероятно, гидроксиды) образуют более неправильные агрегаты, в которых его содержание колеблется от 23,3 до 50,5 мас. \% . В микровлючениях практически всегда встречаются As $(0,4-1,5$ мac. $\%)$, а также P $(0,3-0,9$ мaсc. $\%)$, Si $(0,9-1,5$ мac. $\%), \mathrm{Al}(1,0-1,5$ мac. $\%), \mathrm{Mn}$ $(0,7$ мас. $\%)$ (рис. 9, с).

В отдельных случаях в микровключениях $\mathrm{Fe}$ фиксируется F (до 1,6 мас. \%), Si (2,8 мас. \%), Al $(0,4$ мас. $\%)$ и не обнаруживаются другие примесные элементы, характерные для гидроксидов. Возможно, что в данном случае мы имеем дело с реликтовым магнетитом первичных пород (рис. $9, d$ ).

В образцах также обнаружена разновидность Fe-содержащего минерала с $\mathrm{Ti}: \mathrm{Fe}-23$ мас. \% , Ti- 

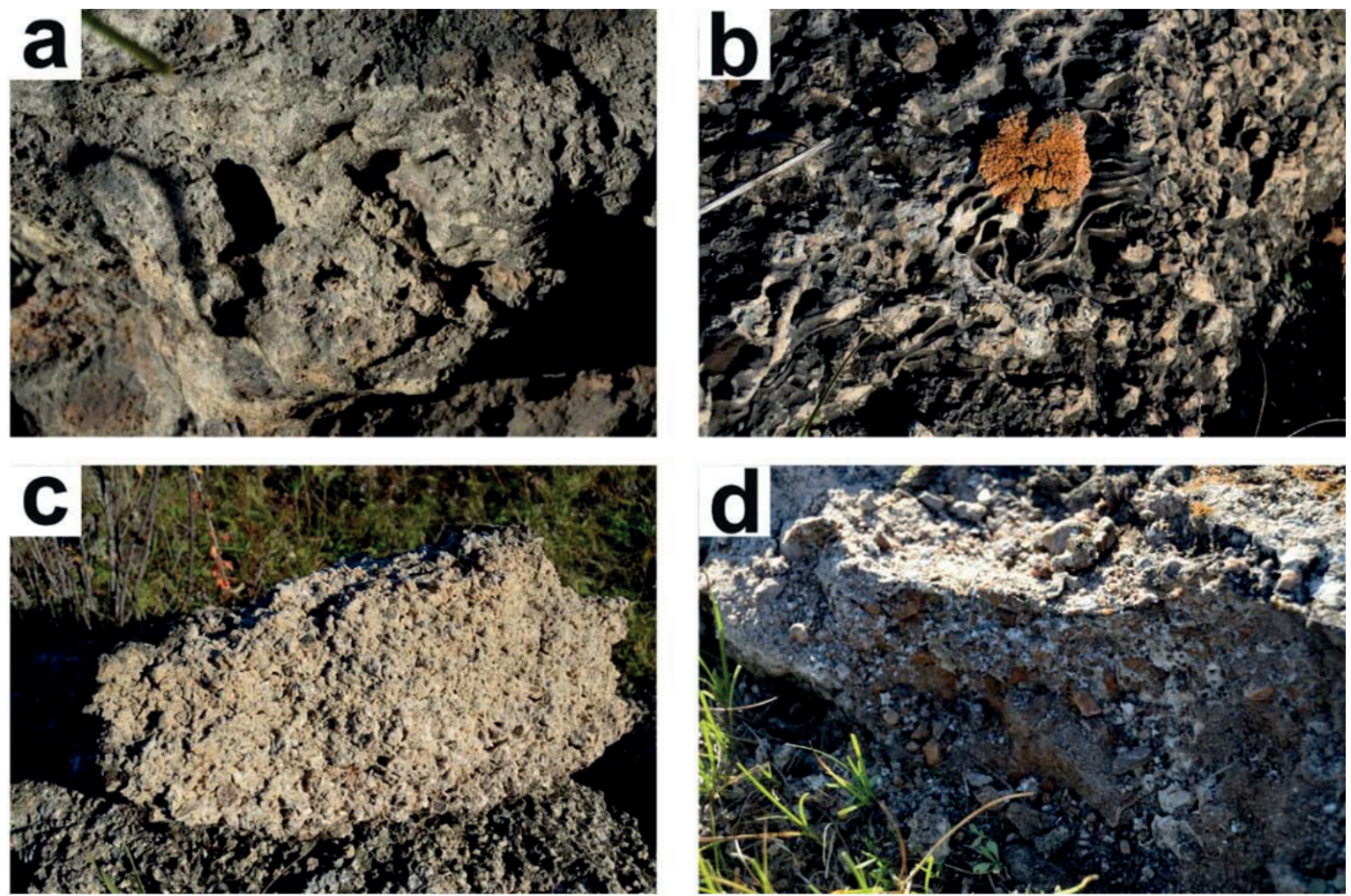

Рис. 8. Текстурно-структурные особенности травертинов: а) серые, пепельно-серые до темно-серых массивные слабо пористые кавернозные породы с налетом Fe-Mn образований; b) телно-серый с участкали светло-серого ивета, кавернозный, неравнолерно ячеистый, разлер ячеек до 3-5 сл; с) телно-серый (внизу) и светло-серый слабо пористый; d) залещение гравелистых осадков карбонатныл материалом, обломки разлером до 2 см, хорошо окатаны и представлены кварцем и полевыми шпатали

Fig. 8. Textural and structural features of travertines: a) gray, ash gray up to dark gray massive weakly porous cavernous rocks with a patina of Fe-Mn sediments; b) dark gray with parts of light gray, cavernous, unevenly cellular, cell size up to 3-5 cm; c) dark gray (bottom part) and light gray slightly porous; d) replacement of gravel sediments with carbonate material, fragments up to $2 \mathrm{~cm}$, well rounded and represented by quartz and feldspars

16,1 мас. \% , Si - 9,7 мас. \% . Данный минерал, вероятно, также является реликтом обломочных пород (рис. $9, e)$.

Иногда в железистом осадке отмечаются интерметаллические соединения $\mathrm{Cu}(81,4$ мас. \%) и $\mathrm{Sn}$ $(15,7$ мас. \%) с примесью Fe $(1,4$ масс. \%) и $\mathrm{Ca}$ $(0,8$ мас. \%). Нельзя исключить техногенное происхождение данного материала, но следует отметить факт его обнаружения и присутствия в нем $\mathrm{Fe}$ и $\mathrm{Ca}$ - элементов, характерных для травертинов.

Травертины имеют тот же состав, что и слаболитифицированные железистые осадки, и сложены преимущественно карбонатом Са $(26-36$ мас. \%) с примесью $\mathrm{Mg}(0,8-1,5$ мас. \% ). На его долю приходится 80-90\% всей матрицы породы. Поры в породе заполнены соединениями $\mathrm{Mn}(11,3-36,7$ мас. \%) и $\mathrm{Fe}(4,2-7,9$ мас. \%) (рис. $10, a)$, в которых также встречаются элементы, обнаруженные и в железистых осадках: $\mathrm{Ba}(0,8-2,6$ мас. \% $), \mathrm{K}(0,1-0,6$ мас. \% ), $\mathrm{Cl}(0,1-0,4$ мас. \%), $\mathrm{Na}(0,5-0,9$ мac. \%), $\mathrm{P}$ $(0,2$ масс. \%), следовые концентрации S. Это свидетельствует, во-первых, об унаследованности состава железистых осадков и травертинов, во-вторых, о том, что процесс травертинообразования проявляется и в настоящее время.
Небезынтересно отметить, что в травертинах нами обнаружен сульфид As (As - 60,5 мас. \%, $\mathrm{Fe}-36,4$ мас. \%) типа лёллингита (рис. $10, b)$, редкоземельный карбонат (Ce - 38,7 мас. \%, La 30 мaс. $\%, \mathrm{Ca}-3,6$ мac. $\%, \mathrm{Fe}-0,7$ мac. \%) (рис. $10, c)$, циркон $(\mathrm{Zr}-51,8$ мас. \%, Si 15,8 мас. \%, $\mathrm{Hf}-1,8$ мас. \% ), по-видимому, имеющий терригенное происхождение (рис. $10, d$ ).

Так называемая «ямкунская пена» и солевые отложения, отобранные на трубе каптажного колодца, по данным сканирующей электронной микроскопии характеризуются также достаточно однородным составом: карбонат $\mathrm{Ca}$ («пена») и $\mathrm{Mg}$ (солевые отложения) (рис. $11, a, b)$. Из интересных находок стоит отметить обнаружение в «пене» карбоната $\mathrm{Ca}-\mathrm{Fe}(\mathrm{Ca}-21,7$ мac. \%, $\mathrm{Fe}-20,1$ мac. \%), который формирует почкообразные агрегаты (рис. $11, c)$. В солевых отложениях нами зафиксирован сульфат Ва (барит?) (рис. $11, d)$.

Изучение биологических материалов (лишайники, мхи, хвоя сосны, листья тополя), отобранных в непосредственной близости к озеру и ручью, показывает, что для них характерны повышенные концентрации U, вероятно, обусловленные влиянием вод. 

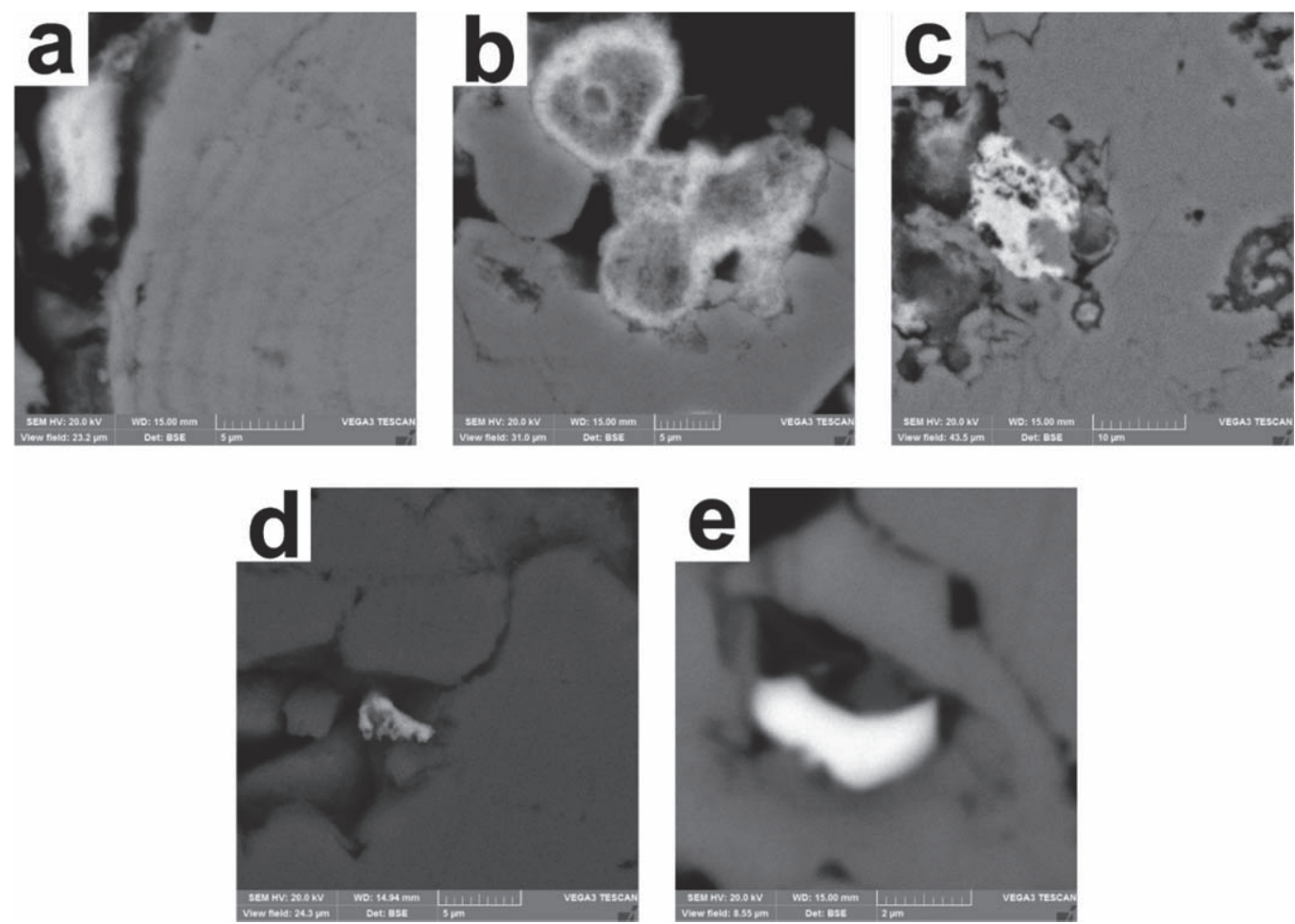

Pис. 9. СЭМ-изображения железистых осадков из ручья и микровключений в их составе: а) зональность; b) соединения $M n$ (сфероид); c) соединения Fe (гидроксиды); d) соединения Fe (реликты); е) Fe-Ti соединение

Fig. 9. SEM-images of ferruginous deposits in the spring and microinclusions in these deposits: a) zonal sequence; $b$ ) Mn compounds (spheroid); c) Fe compounds (hydroxides); d) Fe compounds (relics); e) Fe-Ti compound
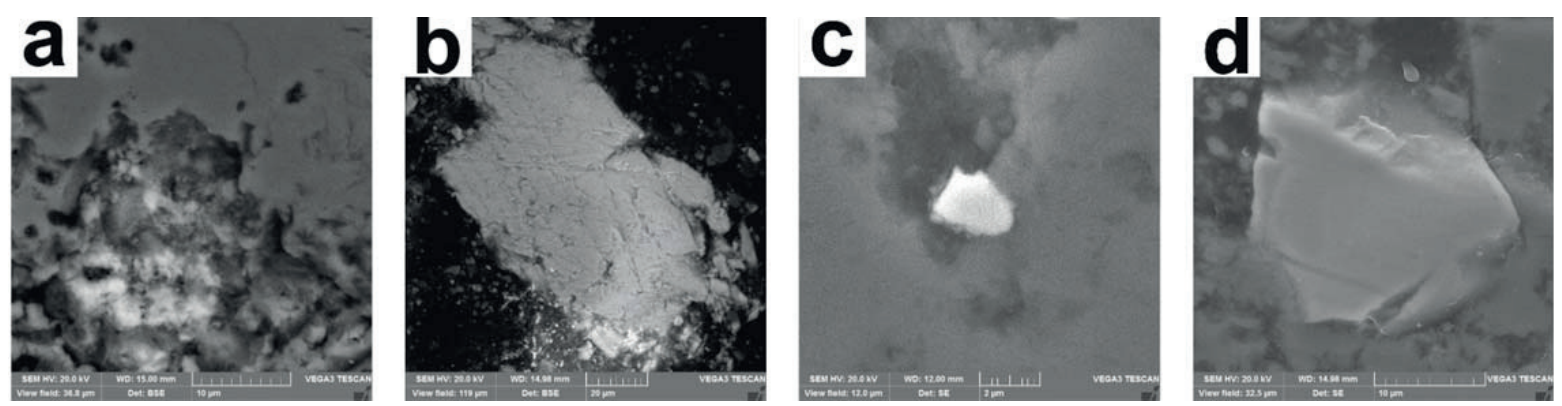

Pис. 10. СЭМ-изображения микровключений в травертинах: a) соединение Mn u Fe; b) сульфид As; c) карбонат La-Ce; d) циркон

Fig. 10. SEM-images of microinclusions in travertines: a) Mn and Fe compound; b) As sulfide; c) La-Ce carbonate; d) zircon
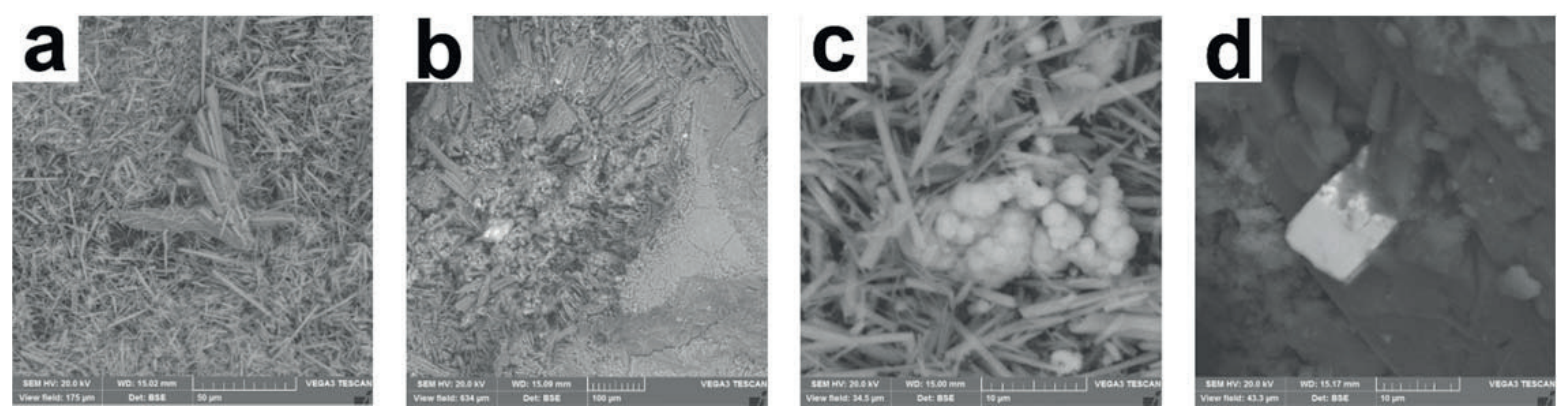

Рис. 11. СЭМ-изображения «пены», солевых отложений с трубы каптажного колодиа и микровключений в их составе: а) общий вид «пены», b) общий вид солевых отложений; с) карбонат $\mathrm{Ca}-\mathrm{Fe}$; d) сульфат Ba

Fig. 11. SEM-images of "foam», salt deposits on the tube of soak well and microinclusions in these deposits: a) general view of "foam»; b) general view of salt deposits; c) Ca-Fe carbonate; d) Ba sulfate 


\section{Заключение}

Исследование источника Ямкун, воды которого широко использовались как эффективное терапевтическое средство при лечении болезни Кашина-Бека (уровская болезнь), показало, что субтермальные воды являются гидрокарбонатными кальциево-магниевыми, радиоактивными радоновой природы. Они существенно обогащены $\mathrm{Mn}, \mathrm{Fe}$, $\mathrm{Be}, \mathrm{As}, \mathrm{Zr}, \mathrm{Cs}, \mathrm{Hg}$, Tl, Li, Co, Ва относительно воды оз. Байкал.

Геохимический спектр воды уникален по своим ассоциациям: с одной стороны, $\mathrm{Fe}, \mathrm{Mn}, \mathrm{Mg}$, с другой стороны, редкие щелочные и щелочноземельные элементы (Li, Be, Cs). Также примечательной является третья группа элементов ( $\mathrm{Hg}, \mathrm{Tl}, \mathrm{As})$. Особняком выглядит $\mathrm{Zr}$, но с точки зрения возможных источников поступления химических элементов в воду он помогает понять их происхождение. С большой долей вероятности таковыми являются редкометалльные гранитоиды.

Разгрузка вод на поверхность приводит к процессам современного минералообразования: в водных ваннах - «ямкунская пена» (арагонит), на трубах каптажного колодца (несквегонит) и в русле ру-

\section{СПИСОК ЛИТЕРАТУРЫ}

1. Thermal and Mineral Waters: Origin, Properties and Applications / eds. W. Balderer, A. Porowski, H. Idris, J.W. LaMoreaux. - Berlin; Heidelberg: Springer-Verlag, 2014. - 135 p.

2. Mineral and Thermal Waters of Southeastern Europe / ed. by P. Papic. - Cham: Springer International Publishing, 2016. $171 \mathrm{p}$.

3. The origin of geothermal waters in Morocco: Multiple isotope tracers for delineating sources of water-rock interactions L. Bouchaou, N.R. Warner, T. Tagma, M. Hssaisoune, A. Vengosh // Applied Geochemistry. - 2017. - V. 84. - P. 244-253.

4. Chenaker H., Houha B., Vincent V. Hydrogeochemistry and geothermometry of thermal water from north-eastern Algeria / Geothermics. - 2018. - V. 75. - P. 137-145.

5. Okan Ö.Ö., Kalender L., Cetindağ B. Trace-element hydrogeochemistry of thermal waters of Karakoçan (Elazığ) and Mazgirt (Tunceli), Eastern Anatolia, Turkey // Journal of Geochemical Exploration. - 2018. - V. 194. - P. 29-43.

6. Geochemistry of the thermal waters in Jiangxi Province, China S.L. Shvartsev, Z. Sun, S.V. Borzenko, B. Gao, O.G. Tokarenko, E.V.Zippa // Applied Geochemistry. - 2018. - V. 96. - P. 113-130.

7. Geochemistry of thermal waters of continental margin of Far East of Russia / I.V. Bragin, G.A. Chelnokov, 0.V. Chudaev, N.A. Kharitonova, S.V. Vysotskiy // Acta Geologica Sinica - English Edition. - 2016. - V. 90. - № 1. - P. 276-284.

8. Geochemistry of Zr, Hf, and REE in a wide spectrum of Eh and water composition: The case of Dead Sea Fault system (Israel) / P. Censi, M. Raso, Y. Yechieli, H. Ginat, F. Salano, P. Zuddas, L. Brusca, W. D'Alessandro, C. Inguaggiato // Geochemistry, Geophysics, Geosystems. - 2017. - V. 18. - № 3. - P. 844-857.

9. Lavrushin V.Yu., Kuleshov V.N., Kikvadze O.E. Travertines of the northern Caucasus // Lithology and Mineral Resources. 2006. - V. 41. - № 2. - P. 137-164.

10. Stable isotope geochemical study of Pamukkale travertines: New evidences of low-temperature non-equilibrium calcite-water fractionation / S. Kele, M. Özkul, I. Fórizs, A. Gökgöz, M.0. Baykara, M.C. Alçiçek, T. Németh // Sedimentary Geology. - 2011. V. 238. - № 1-2. - P. 191-212. чья (железистые осадки). Железистые осадки представлены магнезиальным кальцитом, насыщенным соединениями $\mathrm{Fe}$ и $\mathrm{Mn}$, вероятно гидроксидами. В гидроксидах $\mathrm{Mn}$ встречаются $\mathrm{Ba}, \mathrm{K}, \mathrm{Cl}$, в то время как в гидроксидах $\mathrm{Fe}-\mathrm{As}, \mathrm{P}, \mathrm{Si}, \mathrm{Al}$. Такой же минеральный состав характерен для травертинов. Из редких микровключений в них следует отметить интерметаллические соединения $\mathrm{Cu}$ и $\mathrm{Sn}$, La-Ce карбонат, а также сульфид As (леллингит?).

Установлена унаследованность состава железистых осадков и травертинов. Образующиеся травертины обогащены теми же элементами, что и вода в источнике. Процесс травертинообразования проявляется и в настоящее время. Субтермальные воды создают условия для метасоматического замещения осадков.

Таким образом, лечебные свойства вод определяются комплексным характером воздействия самих вод, присутствием радона и растворенных микрокомпонентов, а также терапевтическими свойствами ландшафта.

Научные исследования выполнены в рамках программы повышения конкурентоспособности ТПУ среди ведущих мировых исследовательских иентров.

11. Comparison of the Quaternary travertine sites in the Denizli extensional basin based on their depositional and geochemical data / M. Özkul, S. Kele, A. Gökgöz, Ch.-Ch. Shen, B. Jones, M.O. Baykara, I. Fórizs, T. Németh, Yu-W. Chang, M.C. Alçiçek // Sedimentary Geology. - 2013. - V. 294. - P. 179-204.

12. Mineralogical-geochemical features of travertines of the modern continental hydrotherms: A G-1 well, Tunka depression, Baikal rift zone / B.R. Soktoev, L.P. Rikhvanov, S.S. Ilenok, N.V. Baranovskaya, T.T. Taisaev // Geology of Ore Deposits.- 2015. V. 57. - № 4. - P. 331-347.

13. A global review on ambient Limestone-Precipitating Springs (LPS): Hydrogeological setting, ecology, and conservation / M. Cantonati, S. Segadelli, K. Ogata, H. Tran, D. Sanders, R. Gerecke, E. Rott, M. Filippini, A. Gargini, F. Celico // Science of the Total Environment. - 2016. - V. 568. - P. 624-637.

14. Origins of elements building travertine and tufa: New perspectives provided by isotopic and geochemical tracers / P.-A. Teboul, C. Durlet, E.C. Gaucher, A. Virgone, J.-P. Girard, J. Curie, B. Lopez, G.F. Camoin // Sedimentary Geology. - 2016. V. 334. - P. 97-114.

15. Geochemistry and Stable Isotopes of Travertine from Jordan Valley and Dead Sea Areas / K.M. Ibrahim, I.M. Makhlouf, A.R.E. Naqah, S.M. Al-Thawabteh // Minerals. - 2017. - V. 7. № 7. - Article number 82.

16. Jones B. Review of calcium carbonate polymorph precipitation in spring systems // Sedimentary Geology. - 2017. - V. 353. P. 64-75.

17. Jones B. Review of aragonite and calcite crystal morphogenesis in thermal spring systems // Sedimentary Geology. - 2017. V. 354. - P. 9-23.

18. Багашев И.А. Минеральные источники Забайкалья: Приложение к Запискам Читинского отделения Приамурского отдела Российского географического общества. - М.: Изд-во М.Д. Бутина, 1905. $-159 \mathrm{c}$.

19. Минеральные воды южной части Восточной Сибири. - М.; Л.: Изд-во Академии наук СССР, 1961. - Т. 1. - 345 с.

20. Минеральные воды южной части Восточной Сибири. - М.; Л.: Изд-во Академии наук СССР, 1962. - Т. 2. - 199 с. 
21. Малая энциклопедия Забайкалья: природное наследие / гл. ред. Р.Ф. Гениатулин. - Новосибирск: Наука, 2009. $698 \mathrm{c.}$

22. Замана Л.В. Гидроминеральные ресурсы Забайкальского края // Курортная база и природные лечебно-оздоровительные местности Тувы и сопредельных регионов. - 2015. - № 2. C. 131-134.

23. Багашев И.А. Радиоактивность источников Забайкалья // Сборник в честь двадцатипятилетия научной деятельности Владимира Ивановича Вернадского. - М.: Типолитография т0варищества И.Н. Кушнерев и Ко, 1914. - С. 29-41.

24. Оргильянов А.И., Крюкова И.Г., Бадминов П.С. Минеральные углекислые воды месторождения Ямкун (Восточное Забайкалье) // Современные проблемы гидрогеологии, инженерной геологии и гидрогеоэкологии Евразии: материалы Всероссийской конференции. - Томск: Изд-во Томского политехнического университета, 2015. - С. 446-450.

25. Замана Л.В. Геохимические особенности углекислых вод Восточного Забайкалья // Современные проблемы гидрогеологии, инженерной геологии и гидрогеоэкологии Евразии: материалы Всероссийской конференции. - Томск: Изд-во Томского политехнического университета, 2015. - С. 160-164.

26. Замана Л.В. Углекислые воды Даурской гидроминеральной области (Восточное Забайкалье) // Вопросы курортологии, физиотерапии и лечебной физической культуры. - 2018. T. 95. - № 4. - C. 69-74.

27. Толстихин Н.И. Газы Восточного Забайкалья. - М.; Л.: Изд-во Академии СССР, 1932. - 40 с.

28. Погребняк Ю.Ф., Толочко В.В., Малясова З.В. Геохимия золота и урана в природных водах Забайкалья // Геохимия радиоактивных элементов и золота Забайкалья. - Новосибирск: Изд-во «Наука», 1979. - С. 120-124.

29. Vetrov V.A., Kuznetsova A.I., Sklyarova 0.A. Baseline levels of chemical elements in the water of Lake Baikal // Geography and Natural Resources. - 2013. - V. 34. - P. 228-238.

Поступила 26.11.2018 г.

\section{Информация об авторах}

Соктоев Б.P., кандидат геолого-минералогических наук, старший преподаватель отделения геологии Инженерной школы природных ресурсов Национального исследовательского Томского политехнического университета.

Рихванов Л.П., доктор геолого-минералогических наук, профессор отделения геологии Инженерной школы природных ресурсов Национального исследовательского Томского политехнического университета.

Барановская H.B., доктор биологических наук, профессор отделения геологии Инженерной школы природных ресурсов Национального исследовательского Томского политехнического университета.

Замана Л.В., кандидат геолого-минералогических наук, ведущий научный сотрудник лаборатории геоэкологии и гидрогеохимии Института природных ресурсов, экологии и криологии Сибирского отделения Российской академии наук.

Рудмин M.A., кандидат геолого-минералогических наук, доцент отделения геологии Инженерной школы природных ресурсов Национального исследовательского Томского политехнического университета.

Эпова E.C., кандидат геолого-минералогических наук, научный сотрудник лаборатории геохимии и рудогенеза Института природных ресурсов, экологии и криологии Сибирского отделения Российской академии наук.

Солодухина M.A., кандидат географических наук, научный сотрудник лаборатории геохимии и рудогенеза Института природных ресурсов, экологии и криологии Сибирского отделения Российской академии наук.

Этенко $\boldsymbol{K} . \boldsymbol{A}$., магистрант кафедры геологии полезных ископаемых геологического факультета Иркутского государственного университета.

Михайлова Л.А., кандидат медицинских наук, заведующий кафедрой гигиены Читинской государственной медицинской академии.

Холмогорова И.В., главный врач краевого центра медицинской реабилитации «Ямкун». 
UDC 553.7.08:550.4:549(571.55)

\section{MINERAL AND GEOCHEMICAL FEATURES OF YAMKUN SPRING (TRANSBAIKAL REGION)}

\author{
Bulat R. Soktoev', \\ bulatsoktoev@tpu.ru
}

Leonid P. Rikhvanov',

rikhvanov@tpu.ru

Natalia V. Baranovskaya',
nata@tpu.ru

Leonid V. Zamana ${ }^{2}$,

I.v.zamana@mail.ru

Maxim A. Rudmin',

rudminma@tpu.ru

\author{
Ekaterina S. Epova², \\ apikur1@ya.ru
}

\author{
Mariya A. Solodukhina², \\ mabn@ya.ru
}

Konstantin A. Etenko33,
konstantin196@gmail.com

Larisa A. Mikhailova ${ }^{4}$,

mihailova-la@mail.ru

\footnotetext{
1 National Research Tomsk Polytechnic University, 30, Lenin Avenue, Tomsk, 634050, Russia.

2 Institute of Natural Resources, Ecology and Cryology of the Siberian Branch of the Russian Academy of Sciences, 16a, Nedorezov street, Chita, 672002, Russia.

${ }^{3}$ Irkutsk State University,

1, Karl Marx street, Irkutsk, 664003, Russia.

${ }^{4}$ Chita State Medical Academy,

39a, Gorky street, Chita, 672000, Russia.

${ }^{5}$ Regional Center of Medical Rehabilitation «Yamkun»,

1, Rabochaya street, Yamkun, 673632, Russia.
}

The relevance. Yamkun spring is known as one of the few radioactive springs in Transbaikal region. Its waters were used for the treatment of Kaschin-Beck disease (Urov disease), nowadays the regional center of medical rehabilitation for the treatment of diseases of the musculoskeletal and nervous systems, including cerebral palsy, and diseases of the skin is working on the basis of this spring. The main aim of the research is to identify mineralogical and geochemical characteristics of Yamkun spring components.

Objects: lake and stream water, travertines, ferruginous sediments in the stream bed, salt sediments on the tube of soak well, vegetation (lichens, mosses, pine straw, poplar leaves).

Methods: inductively coupled plasma mass-spectrometry, instrumental neutron activation analysis, X-ray diffractometry, scanning electron microscopy.

Results. Water of Yamkun spring is bicarbonate, calcium-magnesium, radioactive of radon nature. It is significantly enriched in $\mathrm{Mn}$, $\mathrm{Fe}$, $\mathrm{Be}, \mathrm{As}, \mathrm{Zr}, \mathrm{Cs}, \mathrm{Hg}, \mathrm{TI}, \mathrm{Li}, \mathrm{Co}$ and Ba relative to water of Lake Baikal. Water enrichment with rare alkaline and alkaline-earth elements ( $\mathrm{Li}$, $\mathrm{Be}, \mathrm{Cs}$ ), as well as $\mathrm{Hg}, \mathrm{Tl}$, As and Zr suggests that their source is rare-metal granitoids. During water discharge we observed modern mineral formation on the surface of water baths as "Yamkun foam» (aragonite), tubes of soak well (nesquehonite) and in the stream (ferruginous sediments). Ferruginous sediments and travertines are represented mainly with magnesian calcite. In the ferruginous sediments we identified in large quantities Fe and Mn compounds, probably hydroxides. The hydroxides of Mn also include Ba, K, Cl compounds, Fe hydroxides - As, P, Si, Al. Rare microinclusions in the travertines are represented with intermetallic phases of Cu and Sn, La-Ce carbonate and As sulphide (loellingite?). The inheritance of composition of modern ferruginous sediments and travertines is established. The forming travertines are enriched with the same elements as the water in the spring.

\section{Key words:}

Yamkun, mineral waters, travertines, ferruginous sediments, mineral composition, chemical composition

The research was carried out within the Program of TPU Competitiveness Enhancement among the leading world research centers.

\section{REFERENCES}

1. Thermal and Mineral Waters: Origin, Properties and Applications. Eds. W. Balderer, A. Porowski, H. Idris, J.W. LaMoreaux. Berlin, Heidelberg, Springer-Verlag, 2014. 135 p.

2. Mineral and Thermal Waters of Southeastern Europe. Ed. by P. Papic. Cham, Springer International Publishing, 2016. 171 p.
3. Bouchaou L., Warner N.R., Tagma T., Hssaisoune M., Vengosh A. The origin of geothermal waters in Morocco: Multiple isotope tracers for delineating sources of water-rock interactions. Applied Geochemistry, 2017, vol. 84, pp. 244-253.

4. Chenaker H., Houha B., Vincent V. Hydrogeochemistry and geothermometry of thermal water from north-eastern Algeria. Geothermics, 2018, vol. 75, pp. 137-145. 
5. Okan Ö.Ö., Kalender L., Çetindağ B. Trace-element hydrogeochemistry of thermal waters of Karakoçan (Elazıg) and Mazgirt (Tunceli), Eastern Anatolia, Turkey. Journal of Geochemical Exploration, 2018, vol. 194, pp. 29-43.

6. Shvartsev S.L., Sun Z., Borzenko S.V., Gao B., Tokarenko 0.G., Zippa E.V. Geochemistry of the thermal waters in Jiangxi Province, China. Applied Geochemistry, 2018, vol. 96, pp. 113-130.

7. Bragin I.V., Chelnokov G.A., Chudaev 0.V., Kharitonova N.A., Vysotskiy S.V. Geochemistry of thermal waters of continental margin of Far East of Russia. Acta Geologica Sinica - English Edition, 2016, vol. 90, no. 1, pp. 276-284.

8. Censi P., Raso M., Yechieli Y., Ginat H., Salano F., Zuddas P., Brusca L., D'Alessandro W., Inguaggiato C. Geochemistry of Zr, $\mathrm{Hf}$, and REE in a wide spectrum of Eh and water composition: The case of Dead Sea Fault system (Israel). Geochemistry, Geophysics, Geosystems, 2017, vol. 18, no. 3, pp. 844-857.

9. Lavrushin V.Yu., Kuleshov V.N., Kikvadze O.E. Travertines of the northern Caucasus. Lithology and Mineral Resources, 2006, vol. 41, no. 2, pp. 137-164.

10. Kele S., Özkul M., Fórizs I., Gökgöz A., Baykara M.0., Alçiçek M.C., Németh T. Stable isotope geochemical study of Pamukkale travertines: New evidences of low-temperature nonequilibrium calcite-water fractionation. Sedimentary Geology, 2011, vol. 238, no. 1-2, pp. 191-212.

11. Özkul M., Kele S., Gökgöz A., Shen Ch.-Ch., Jones B., Baykara M.O., Fórizs I., Németh T., Chang Yu-W., Alçiçek M.C. Comparison of the Quaternary travertine sites in the Denizli extensional basin based on their depositional and geochemical data. Sedimentary Geology, 2013, vol. 294, pp. 179-204.

12. Soktoev B.R., Rikhvanov L.P., Ilenok S.S., Baranovskaya N.V., Taisaev T.T. Mineralogical-geochemical features of travertines of the modern continental hydrotherms: A G-1 well, Tunka depression, Baikal rift zone. Geology of Ore Deposits, 2015, vol. 57, no. 4, pp. 331-347.

13. Cantonati M., Segadelli S., Ogata K., Tran H., Sanders D., Gerecke R., Rott E., Filippini M., Gargini A., Celico F. A global review on ambient Limestone-Precipitating Springs (LPS): Hydrogeological setting, ecology, and conservation. Science of the Total Environment, 2016, vol. 568, pp. 624-637.

14. Teboul P.-A., Durlet C., Gaucher E.C., Virgone A., Girard J.-P., Curie J., Lopez B., Camoin G.F. Origins of elements building travertine and tufa: New perspectives provided by isotopic and geochemical tracers. Sedimentary Geology, 2016, vol. 334, pp. $97-114$.

15. Ibrahim K.M., Makhlouf I.M., Naqah A.R.E., Al-Thawabteh S.M. Geochemistry and Stable Isotopes of Travertine from Jordan Valley and Dead Sea Areas. Minerals, 2017, vol. 7, no. 7, article number 82.

16. Jones B. Review of calcium carbonate polymorph precipitation in spring systems. Sedimentary Geology, 2017, vol. 353, pp. 64-75.

17. Jones B. Review of aragonite and calcite crystal morphogenesis in thermal spring systems. Sedimentary Geology, 2017, vol. 354, pp. 9-23.

18. Bagashev I.A. Mineralnye istochniki Zabaykalya: Prilozheniya $k$ Zapiskam Chitinskogo otdeleniya Priamurskogo otdela Rossiyskogo geograficheskogo obshchestva [Mineral springs of Transbaikalia: Appendix to the Notes of the Chita office, Amur branch, Rus- sian geographical society]. Moscow, M.D. Butin's Publ., 1905. $159 \mathrm{p}$.

19. Mineralnye vody yuzhnoy chasti Vostochnoy Sibiri [Mineral waters of the southern part of Eastern Siberia]. Moscow, Leningrad, Academy of Sciences of the USSR Publ., 1961. Vol. 1, 345 p.

20. Mineralnye vody yuzhnoy chasti Vostochnoy Sibiri [Mineral waters of the southern part of Eastern Siberia]. Moscow, Leningrad, Academy of Sciences of the USSR Publ., 1962. Vol. 2, $199 \mathrm{p}$.

21. Malaya entsiklopediya Zabaykalya: Prirodnoe nasledie [Small encyclopedia of Transbaikalia: Natural heritage]. Ed. by R.F. Geniatulin. Novosibirsk, Nauka Publ., 2009. 698 p.

22. Zamana L.V. Gidromineralnye resursy Zabaykalskogo kraya [Hydromineral resources of Zabaikalskiy krai]. Kurortnaya baza $i$ prirodnye lechebno-ozdorovitelnye mestnosti Tuvy i sopredelnykh regionov, 2015, vol. 2, pp. 131-134.

23. Bagashev I.A. Radioaktivnost istochnikov Zabaykalya [The radioactivity of the springs of Transbaikalia]. Sbornik $v$ chest dvadtsatipyatiletiya nauchnoy deyatelnosti Vladimira Ivanovicha Vernadskogo [Collection in honor of the twenty-fifth anniversary of scientific activity of Vladimir Vernadsky]. Moscow, I.N. Kushnerev and Co company typolithography, 1914. pp. 29-41.

24. Orgilyanov A.I., Kryukova A.I., Badminov P.S. Mineralnye uglekislye vody mestorozhdeniya Yamkun (Vostochnoe Zabaykale [Mineral carbon dioxide waters of Yamkun deposit (Eastern Transbaikalia)]. Sovremennye problemy gidrogeologii, inzhenernoy geologii i gidrogeoecologii Evrazii. Materialy Vserossiyskoy konferentsii [Modern problems of hydrogeology, engineering geology and hydrogeoecology of Eurasia. Proc. of the All-Russian conference]. Tomsk, Tomsk Polytechnic University Publ. house, 2015. pp. 446-450.

25. Zamana L.V. Geokhimicheskie osobennosti uglekislykh vod Vostochnogo Zabaykalya [The geochemical characteristics of the carbon dioxide waters of the Eastern Transbaikalia]. Souremennye problemy gidrogeologii, inzhenernoy geologii i gidrogeoekologii Evrazii: materialy Vserossiyskoy konferentsii [Modern problems of hydrogeology, engineering geology and hydrogeoecology of Eurasia. Proc. of the All-Russian conference]. Tomsk, Tomsk Polytechnic University Publ. house, 2015. pp. 160-164.

26. Zamana L.V. Carbon dioxide waters of the Daurian hydromineral region (Eastern Transbaikalia). Problems of Balneology, Physiotherapy, and Exercise Therapy, 2018, vol. 95, no. 4, pp. 69-74. In Rus.

27. Tolstikhin N.I. Gazy Vostochnogo Zabaykalya [Gases of Eastern Transbaikalia]. Moscow, Leningrad, Academy of Sciences of the USSR Publ., 1932. 40 p.

28. Pogrebnyak Yu.F., Tolochko V.V., Malyasova Z.V. Geokhimiya zolota i urana v priridnykh vodakh Zabaykalya [Geochemistry of gold and uranium in natural waters of Transbaikalia]. Geokhimiya radioaktiunykh elementov $i$ zolota Zabaykalya [Geochemistry of radioactive elements and gold in Transbaikalia]. Novosibirsk, Nauka Publ., 1979. pp. 120-124.

29. Vetrov V.A., Kuznetsova A.I., Sklyarova 0.A. Baseline levels of chemical elements in the water of Lake Baikal. Geography and $\mathrm{Na}$ tural Resources, 2013, vol. 34, pp. 228-238.

Received: 26 November 2018. 


\section{Information about the authors}

Bulat R. Soktoev, Cand. Sc., assistant professor, National Research Tomsk Polytechnic University.

Leonid P. Rikhvanov, Dr. Sc., professor, National Research Tomsk Polytechnic University.

Natalia V. Baranovskaya, Dr. Sc., professor, National Research Tomsk Polytechnic University.

Leonid V. Zamana, Cand. Sc., leading research scientist, Institute of Natural Resources, Environment, and Cryology. Maxim A. Rudmin, Cand. Sc., associate professor, National Research Tomsk Polytechnic University.

Ekaterina S. Epova, Cand. Sc., research scientist, Institute of Natural Resources, Environment, and Cryology.

Mariya A. Solodukhina, Cand. Sc., research scientist, Institute of Natural Resources, Environment, and Cryology.

Konstantin A. Etenko, master student, Irkutsk State University.

Larisa A. Mikhailova, Cand. Sc., head of the department, Chita State Medical Academy.

Irina V. Kholmogorova, chief doctor, Regional Center of Medical Rehabilitation «Yamkun». 